\title{
Tropical Legumes Preserved in Silage and Hay Form and Its Nutritional Values in Laboratory Conditions
}

\author{
Fabio Seiji dos Santos \\ Animal Science, State University of Maringa \\ 5790 Colombo Avenue, Maringa, Paraná, Brazil. \\ E-mail: fabio1987_@hotmail.com
}

\begin{abstract}
Alexandre Menezes Dias
Animal Science, Federal University of Mato Grosso do Sul

2443 Senador Filinto Muller Avenue, Campo Grande, Mato Grosso do Sul, Brazil

E-mail: alexandre.menezes@ufms.br
\end{abstract}

Luís Carlos Vinhas Ítavo

Animal Science, Federal University of Mato Grosso do Sul

2443 Senador Filinto Muller Avenue, Campo Grande, Mato Grosso do Sul, Brazil

E-mail: luis.itavo@ufms.br

\author{
Ulysses Cecato \\ Animal Science, State University of Maringa \\ 5790 Colombo Avenue, Maringa, Parana, Brazil. \\ E-mail: ucecato@uem.br
}

Andressa Faccenda

Animal Science, State University of Maringa

5790 Colombo Avenue, Maringa, Parana, Brazil.

E-mail: andressafaccenda@hotmail.com 
Maximiliane Alavarse Zambom

Animal Science, State University of Western Parana

1777 Pernambuco Street, Marechal Cândido Rondon, Parana, Brazil.

E-mail: mazambom@hotmail.com

Geraldo Tadeu dos Santos (Corresponding author)

National Institute of Science and Technology of Dairy Production Chain (INCTLeite/UEL)

State University of Londrina and State University of Maringa

5790 Colombo Avenue, Maringa, Paraná, Brazil.

E-mail: gtsantos50@gmail.com

Received: Oct. 8, $2019 \quad$ Accepted: Nov. 12, $2019 \quad$ Published: Nov. 19, 2019

doi:10.5296/jas.v8i1. URL: https://doi.org/10.5296/jas.v8i1.

\begin{abstract}
This study aimed to evaluate the nutritional value of legumes leucaena and desmodium preserved in hay and silage form. We used a completely randomized design in a $2 \times 2$ factorial arrangement with two bulky conservation methods (hay and silage) and two legumes (leucaena and desmodium). For the bulky characterization was determined chemical composition and total digestible nutrients (TDN). For assessing the nutritional value, analysis of in vitro dry matter digestibility (IVDMD) and cell wall digestibility (IVCWD), and in situ effective degradability of dry matter (EDDM) and crude protein (EDCP) were performed. Data were submitted to ANOVA and Tukey test at 5\% probability. Due to the characteristics of each specie leucaena presented a higher crude protein (CP) and TDN content compared to desmodium and lower fibrous fractions. The IVDMD presented interaction between the conservation form and forage $(\mathrm{P}<0.05)$, where leucaena hay was higher than the others treatments. The IVCWD also presented interaction $(\mathrm{P}<0.05)$, and the best values were obtained for leucaena silage. EDDM was superior in leucaena compared to desmodium $(\mathrm{P}<0.05)$. Regarding the method of preservation, the EDDM was higher in hay compared to silage. For the EDCP there was an interaction between conservation method and forage, where leucaena silage and hay were similar $(\mathrm{P}<0.05)$, but higher than other treatments. Thus, leucaena has a nutritional value higher than desmodium and the conservation of legumes in the hay form presented a higher nutritional value to the conserved as silage.
\end{abstract}

Keywords: bulky, conserved forage, degradability, digestibility, protein 


\section{Introduction}

Tropical legumes, due to their particularities, provide biological cover and nitrogen fixation in the soil, reducing erosion and weed infestation, as well as improving animal feeding due to its high protein content and higher digestibility when compared to grasses (Teixeira et al., 2010). Thus, legumes are alternatives for many areas with tropical pasture.

Among the so-called woody plants, leucaena (Leucaena leucocephala) highligths for adapting in tropical regions, presenting arboreal structure and producing large amounts of edible biomass (Possenti et al., 2008). In addition, it presents function for multiple forms of use, has high acceptability by the animals and excellent ability to regrow (Costa et al., 2011). However, some anti-nutritional factors present in leucaena can affect digestion in ruminants, such as tannin and mimosine (Makkar, 2003; Aganga and Tshwenyane, 2003).

According to Barreto et al. (2010) leucaena presents in its leaves around $10.15 \%$ of tannin. Despite this high tannin level, studies have shown that there is no negative effect of tannins on the production of microbial protein (Makkar, 2003). Possibly, the tannin present in these legumes is more harmful to fibrolytic bacteria than to proteolytic bacteria (Makkar, 2003). In vitro digestibility of leucaena obtained by Manella et al. (2002) were 57.2\% and $61.5 \%$ for the period of water and drought, respectively, which can be considered high values despite high tannin levels. Another antinutritional factor present in leucaena is mimosine, a toxic substance that causes symptoms such as hair loss in ruminants not adapted to consuming it (Almeida et al., 2006), therefore, the use of leucaena in ruminants diets should not exceed $30 \%$ for unadapted animals (Aganga and Tshwenyane, 2003).

Desmodium is a legume whose genus has more than 600 species, among which Desmodium ovalifolium, highlights having excellent adaptation to different soils and climates and provides improvements in soil conditions (Barrios-Maestre et al., 2011).

However, its use in livestock has high tannin contents which affects animals intake and digestibility (Cruz, 1993). According to Abaunza et al. (1991) the tannin content found in $D$. ovalifolium CIAT-350 is around $17 \%$.

In Brazil, a study evaluating several desmodium genotypes was performed in the state of Rondônia, and was observed that D. ovalifolium CIAT-350 was distinguished by its productivity in the rainy season, reaching a yield of 17.3 tons of dry matter (DM) per hectare (Costa and Oliveira, 1999). However, the genotype that was most outstanding by crude protein (CP) levels was D. heterophilum CIAT-349 with $15.2 \% \mathrm{CP}$. The D. ovalifolium CIAT-350 was in an intermediate position, with $12.0 \% \mathrm{CP}$. The IVDMD of these genotypes ranged from $50.3 \%$ for $D$. heterophilum CIAT-3782 to $38.7 \%$ for D. ovalifolium CIAT-350 (Costa and Oliveira, 1999). Macedo et al. (2010) obtained values of in vitro organic matter digestibility of $47.9 \%$ for D. ovalifolium.

Leucaena and desmodium are legume fodders that can be used to feed ruminants as pastures and in the form of conserved fodder, becoming a protein bank for feed shortage periods. In this context, the objective was to evaluate the nutritional value of leucaena and desmodium conserved as hay and silage. 


\section{Material and Methods}

The legumes used in this experiment for the production of hay and silage were established at the Experimental Farm of Iguatemi of the State University of Maringá, Paraná, whose analysis of podozoic soil dark red was with the following conditions: $\mathrm{pH}$ in water 5.8; $\mathrm{Al} \mathrm{+++}$

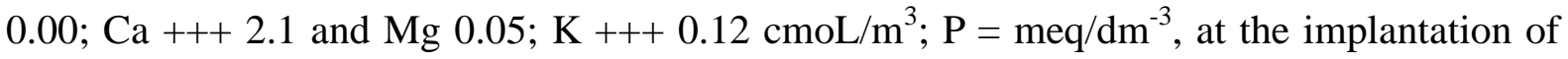
these legumes. For the planting of leucaena (Leucaena leucocephala), seeds were scarified with water at $50{ }^{\circ} \mathrm{C}$ for $10 \mathrm{~min}$. Then, planted with spacing between plants of $1.5 \mathrm{~m}$, totaling five plants / $\mathrm{m}$ linear, in an area of $96 \mathrm{~m}^{2}$, divided into $5 \mathrm{sub}$-areas of $19.2 \mathrm{~m}^{2}$. Desmodium (Desmodium ovalifolium) CIAT-350 seeds were obtained scarified and were planted without inoculation with spacing $25 \mathrm{~cm}$ between plants, in an area of $20 \mathrm{~m}^{2}$, divided into 5 sub-areas of $4 \mathrm{~m}^{2}$.

The cutting of legumes occurred in late January. From leucaena were harvested the leaves and stems of plants and for desmodium cut was performed at $6 \mathrm{~cm}$ above the soil, before the beginning of the flowering phase. The materials were harvested from five uniform sub-areas for both legumes and separated into two fractions of each sub-area, one for hay making and one for silage making. The materials destined to hay production remained exposed to the sun for 18 hours on a tarp and were then turned over. After drying, these materials were packed in paper bags until the moment of laboratory analysis. These procedures, from harvesting and drying, were performed in each of the five sub-areas to obtain the replicates.

The silage materials (five replicates) were pre-wilted for a period of $4 \mathrm{~h}$, then chopped $( \pm 2$ $\mathrm{cm})$. Subsequently, approximately $3 \mathrm{~kg}$ of the material was ensiled in PVC laboratory silos. At the time of ensiling, acetic acid was added in a ratio of $6 \mathrm{~mL}+20 \mathrm{~g}$ of corn meal per $\mathrm{kg}$ of ensiled green matter.

The opening of silos occurred 30 days after ensilage. Immediately after opening the $\mathrm{pH}$ was determined according to Cherney and Cherney (2003). Ammonia nitrogen content $\left[\mathrm{NH}_{3}-\mathrm{N}\right.$ (\% of total N)] was determined according to AOAC (1980). Samples of silages and hay were oven dried at $55^{\circ} \mathrm{C}$ for $72 \mathrm{~h}$, divided into two parts, one part was milled in a knife mill with a $1 \mathrm{~mm}$ sieve for laboratory analysis and another part was milled in knife mill equipped with a $4 \mathrm{~mm}$ sieve screen to determine in situ degradability of DM and CP.

Laboratory analysis for silage and hay characterization including DM, ash, CP, ethereal extract (EE), neutral detergent fiber (NDF) and acid detergent fiber (ADF) were performed as described in Silva and Queiroz (2002). Total digestible nutrients (TDN) were calculated according to Weiss (1993).

In vitro dry matter digestibility (IVDMD) and in vitro cell wall digestibility (IVCWD) were performed using the technique described by Tilley and Terry (1963), adapted for the use of the Daisy II-Ankom ${ }^{\circledR}$ artificial rumen fermenter, proceeding weighing $0.5 \mathrm{~g}$ of sample from each replicate. Cows used as donors of ruminal fluid received total mixed ration (TMR) according to Table 1. This TMR was distributed twice a day, and at intervals the cows remained in a pasture predominating African star (Cynodon nelemfuensis Vanderyst). 
Table 1. Ingredients and daily intake of natural matter and dry matter for cows used as donors of ruminal liquid for in vitro digestibility studies

\begin{tabular}{l|c|c}
\hline Ingredients & Natural matter intake/cow/day $(\mathrm{kg})$ & Dry matter intake/cow/day $(\mathrm{kg})$ \\
\hline Corn silage & 16 & 4.80 \\
\hline Leucaena hay & 1 & 0.85 \\
\hline Desmodium hay & 1 & 0.86 \\
\hline Concentrated feed & 3 & 2.69 \\
\hline Total & 21 & 9.20 \\
\hline
\end{tabular}

*Concentrated feed consisting of $78 \%$ corn, $20 \%$ soybean meal and $2 \%$ mineral salt.

For in situ degradability of DM and CP, samples from each of the five silos were mixed to form a composite sample. The nylon bag $(10 \times 17 \mathrm{~cm})$ technique was used, with pores of $53 \pm$ $10 \mu \mathrm{m}$. The samples were incubated in two non-lactating cows with rumen cannulas at the time intervals: $0,6,9,24,48,72$ and 96 h removing all the samples from the rumen at the same time. Cows were fed the TMR described in Table 1.

Percentages of degradation of DM and $\mathrm{CP}$ at each time were calculated by the proportion of materials remaining in the nylon bags after incubation in the rumen. The degradabilities of DM and CP were calculated using the equation described by Orskov and McDonald (1979).

$$
P=a+b(1-e-c t)
$$

Where:

$\mathrm{P}=$ amount degraded in time $(\mathrm{h}) ; \mathrm{a}=$ intersection of the curve at time zero and can be interpreted with the rapidly soluble fraction; $b=$ represents the potentially degradable fraction, expressing the fraction that was degraded in time $(\mathrm{t}) ; \mathrm{c}=$ fractional rate of degradation in which fraction $b$ was degraded each hour.

The effective degradability of DM (EDDM) and CP (EDCP) in the rumen were calculated using the equation described by Orskov and McDonald (1979):

$$
\operatorname{EDDM} \text { or } \mathrm{EDCP}=\mathrm{a}+[(\mathrm{b} * \mathrm{c}) /(\mathrm{c}+\mathrm{k})]
$$

Where:

$\mathrm{k}=$ represents the fractional particles passage rate in the rumen.

\section{Results and Discussion}

The DM content of leucaena and desmodium hays are within the range recommended by Evangelista and Lima (2013), who pointed out that in the moment of hay production, the 
forage must have a moisture content between $10 \%$ and $18 \%$, so it can be preserved without risk of mold formation (Table 2). The silages of both evaluated forages also presented a DM content within the acceptable for pre-dried silages that are between $35 \%$ and $45 \%$ (Pereira and Reis, 2001).

The values of CP in desmodium are close to $14 \%$ obtained by Morgado et al. (2009) and higher than the $12.75 \%$ reported by Bezerra et al. (2010). For leucaena the CP levels obtained were similar to those described by Costa et al. (2015). The variation in CP, NDF and ADF levels for desmodium in relation to leucaena can be explained by the higher proportion of stems in desmodium, since this structure has higher concentrations of structural carbohydrates and less protein. Veloso et al. (2000) observed a leaf:stem ratio of 2.7: 1 for leucaena, while Teixeira et al. (2010) observed a ratio of 1.1: 1 for the desmodium with 102 days.

Table 2. Chemical composition (\% of dry matter), potential of hydrogen $(\mathrm{pH})$ and ammonia nitrogen $\left(\mathrm{NH}_{3}-\mathrm{N}\right)$ of silage and hay of leucaena (Leucaena leucocephala) and desmodium (Desmodium ovalifolium) CIAT-350

\begin{tabular}{l|c|c|c|c}
\hline \multirow{2}{*}{ Variables } & \multicolumn{2}{|c|}{ Silage } & \multicolumn{2}{c}{ Hay } \\
\cline { 2 - 5 } & Desmodium & Leucaena & Desmodium & Leucaena \\
\hline $\mathrm{DM}(\%$ feed $)$ & 43.61 & 44.66 & 82.53 & 84.34 \\
\hline $\mathrm{OM}$ & 84.68 & 83.11 & 92.14 & 89.73 \\
\hline Ashes & 15.36 & 16.89 & 7.86 & 10.27 \\
\hline $\mathrm{CP}$ & 14.29 & 26.78 & 14.39 & 26.69 \\
\hline $\mathrm{NDF}$ & 65.89 & 39.26 & 58.31 & 32.57 \\
\hline $\mathrm{ADF}$ & 45.32 & 18.60 & 41.83 & 15.65 \\
\hline $\mathrm{EE}$ & 2.72 & 2.37 & 2.69 & 2.25 \\
\hline $\mathrm{TDN}{ }^{1}$ & 60.39 & 78.50 & 61.33 & 73.90 \\
\hline $\mathrm{pH}$ & 4.58 & 4.66 & - & - \\
\hline $\mathrm{NH}{ }_{3}-\mathrm{N}(\%$ total N) & 3.38 & 3.09 & - & - \\
\hline
\end{tabular}

DM: dry matter; OM: organic matter; $\mathrm{CP}$ : crude protein; NDF: neutral detergente fiber; ADF: acid detergente fiber; EE: ethereal extract; TDN: total digestible nutrients. ${ }^{1} \mathrm{TDN}=105.2-(0$. $68 * \mathrm{NDF}$ ) for silage and TDN $=81.41-(0.48 * \mathrm{ADF})$ for hay (Weiss. 1993). 


\section{$\triangle 1$ Macrothink}

The $\mathrm{pH}$ presented by the silages of both legumes was above the range of 3.6 to 4.2 recommended by McDonald et al. (1991) as one of the requirements for good quality silage. However, in silages with higher DM content, stabilization with higher $\mathrm{pH}$ may occur (Pereira and Reis, 2001).

The ammoniacal nitrogen contents of silages were less than $10 \%$ of the total nitrogen, which according to McDonald et al. (1991) classifies these silages as very good quality, since this parameter indicates less proteolysis by bacteria of the genus Clostridium during the fermentation. It is important to note that the high DM content of the silage aided this parameter, since it provided low water availability for the Clostridium development (Schocken-Iturrino et al., 2005).

The IVDMD values showed interaction between the legumes and the conservation method $(\mathrm{P}<0.05)$ where all the treatments differed from each other. Regarding the forage evaluated, the IVDMD of leucaena presented higher values $(\mathrm{P}<0.05)$ than the desmodium (Table 3$)$. Abaunza et al. (1991) and Costa and Oliveira (1999) also observed a low IVDMD of the desmodium (CIAT 350), being 38.3\% and 38.7\%, respectively. These results may have occurred due to the high content of tannin $(17 \%)$ found in this legume that negatively affects its digestibility and decreased its palatability (Abaunza et al., 1991). There were also differences regarding the conservation method, where the highest digestibility occurred for hay $(\mathrm{P}<0.05)$.

Table 3. In vitro dry matter digestibility (IVDMD) and cell wall (IVCWD) (\% of dry matter) of silage and hay of leucaena (Leucaena leucocephala) and desmodium (Desmodium ovalifolium) CIAT-350

\begin{tabular}{l|c|c|c|c|c|c|c|c}
\hline \multirow{2}{*}{ Variables } & \multicolumn{2}{|c|}{ Silage } & \multicolumn{2}{c|}{ Hay } & \multicolumn{3}{c}{ SD } & \multicolumn{3}{c}{ P value } \\
\cline { 2 - 5 } \cline { 7 - 9 } & DESM & LEUC & DESM & LEUC & & CONS & FOR & INT \\
\hline IVDMD & $39.47 \mathrm{~d}$ & $70.86 \mathrm{~b}$ & $48.04 \mathrm{c}$ & $76.70 \mathrm{a}$ & 0.79 & 0.000 & 0.000 & 0.008 \\
\hline IVCWD & $34.62 \mathrm{~d}$ & $57.90 \mathrm{a}$ & $39.26 \mathrm{c}$ & $51.85 \mathrm{~b}$ & 0.48 & 0.131 & 0.000 & 0.000 \\
\hline
\end{tabular}

Averages within the same row, followed by different letters differ from each other at the 5\% probability level for the interaction; $\mathrm{SD}=$ standard deviation; $\mathrm{DESM}=$ Desmodium; $\mathrm{LEUC}=$ Leucaena; CONS = conservation method; FOR = forage; INT = interaction;

The IVCWD did not show any effect in relation to the conservation method $(\mathrm{P}>0.05)$, but differed among the forages tested, being higher for leucaena $(\mathrm{P}<0.05)$. The lowest IVCWD in desmodium occurred due to the higher ADF concentration in this forage, because this fibrous fraction is negatively correlated to the digestibility and increases with the maturity of the plant (Müller et al., 2006). There was interaction between forages and the conservation method $(\mathrm{P}<0.05)$, with the highest IVCWD occurring in the treatment with leucaena silage and the lowest for desmodium silage. 


\section{MlMacrothink}

There were differences for the soluble fraction (a) and slowly degraded fraction of DM in rumen (b) in relation to the conservation methods (Table 4), which were higher for hay $(\mathrm{P}<0.05)$. As for evaluated fodder, leucaena presented values higher than desmodium $(\mathrm{P}<0.05)$. The degradation rate $(\mathrm{c})$ was faster for leucaena $(\mathrm{P}<0.05)$, regardless of the conservation method $(\mathrm{P}>0.05)$.

Table 4. Average of least squares to the nonlinear estimates and effective degradability of dry matter (EDDM) of silage and hay of leucaena (Leucaena leucocephala) and desmodium (Desmodium ovalifolium) CIAT-350

\begin{tabular}{|c|c|c|c|c|c|c|c|c|}
\hline \multirow[t]{2}{*}{ Variables } & \multicolumn{2}{|c|}{ Silage } & \multicolumn{2}{|c|}{ Feno } & \multirow[t]{2}{*}{ SD } & \multicolumn{3}{|c|}{$\mathrm{P}$ value } \\
\hline & DESM & LEUC & DESM & LEUC & & CONS & FOR & INT \\
\hline $\mathrm{a}(\%)$ & $19.84 c$ & $26.87 b$ & $19.80 \mathrm{c}$ & $31.83 a$ & 0.59 & 0.014 & 0.000 & 0.014 \\
\hline $\mathrm{b}(\%)$ & $44.64 b$ & $62.73 a$ & $56.62 \mathrm{a}$ & $62.26 a$ & 1. 28 & 0.015 & 0.001 & 0.006 \\
\hline $\mathrm{c}(\% / \mathrm{h})$ & 3.70 & 5. 20 & 3. 50 & 5.80 & 0.003 & 0.587 & 0.005 & 0.304 \\
\hline EDDM P2 $(\% / \mathrm{h})$ & 48.62 & 72.10 & 55.77 & 77.35 & 0.63 & 0.001 & 0.000 & 0.207 \\
\hline EDDM P5 (\%/h) & 38.66 & 58.77 & 43.09 & 64.69 & 0.94 & 0.005 & 0.000 & 0.475 \\
\hline
\end{tabular}

Averages within the same row, followed by different letters differ from each other at the 5\% probability level for the interaction; $\mathrm{SD}=$ standard deviation; $\mathrm{DESM}=$ Desmodium; LEUC = Leucaena; CONS = conservation method; FOR = Forage; INT = Interaction; $a=$ rapidly soluble fraction; $\mathrm{b}=$ potentially degradable fraction; $\mathrm{c}=$ fractional rate of degradation in which fraction b; EDDM P2 and EDDM P5 = Effective degradability of dry matter at passage rate of 2 and $5 \% / \mathrm{h}$

The EDDM at passage rate 2 and 5\% was superior for leucaena compared to desmodium $(\mathrm{P}<0.05)$. These values agree with Bezerra et al. (2010) who also observed reduced EDDM for the Desmodium canum being 46.61 and $36.05 \%$ for the passage rates of 2 and 5\% respectively, while Pires et al. (2006) obtained 62.9 and 53.9\% of EDDM for leucaena at the same passage rates, respectively. These results may be associated to the higher ADF concentration in the desmodium, since this fibrous fraction has lignin that is not utilized by ruminal microorganisms (Silva and Queiroz, 2002), reducing DM degradability. In relation to the conservation method, the EDDM in the passage rate of 2 and 5\% were higher for hay compared to silage. There was no interaction between the conservation method and the legume species $(\mathrm{P}>0.05)$.

The conservation method and the different legumes did not influence the soluble fraction (a) of $\mathrm{CP}(\mathrm{P}>0.05)$, with an average value of $17.47 \%$ (Table 5). Potentially degradable CP fraction (b) differed between the conservation method and the fodder species, and there was 


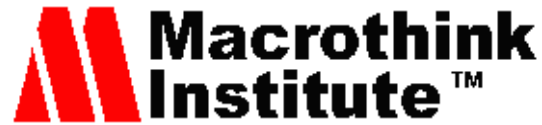

interaction between the factors $(\mathrm{P}<0.05)$. The leucaena conserved in the hay and silage form were similar to each other $(\mathrm{P}>0.05)$ but differed from the desmodium hay that presented intermediate value and the desmodium silage which presented lower value. Degradation rate (c) was faster for leucaena $(\mathrm{P}<0.05)$, regardless of the conservation method $(\mathrm{P}>0.05)$.

Table 5. Average of least squares to the nonlinear estimates and effective degradability of crude protein (EDCP) of silage and hay of leucaena (Leucaena leucocephala) and desmodium (Desmodium ovalifolium) CIAT-350

\begin{tabular}{|c|c|c|c|c|c|c|c|c|}
\hline \multirow[t]{2}{*}{ Variables } & \multicolumn{2}{|c|}{ Silage } & \multicolumn{2}{|c|}{ Hay } & \multirow{2}{*}{$\mathrm{SD}$} & \multicolumn{3}{|c|}{$P$ value } \\
\hline & DESM & LEUC & DESM & LEUC & & CONS & FOR & INT \\
\hline $\mathrm{a}(\%)$ & 16.81 & 18.66 & 18.68 & 15.75 & 0.88 & 0.587 & 0.573 & 0.054 \\
\hline $\mathrm{b}(\%)$ & $50.13 \mathrm{c}$ & $78.19 \mathrm{a}$ & $68.05 \mathrm{~b}$ & $82.91 \mathrm{a}$ & 1.53 & 0.002 & 0.000 & 0.013 \\
\hline $\mathrm{c}(\% / \mathrm{h})$ & 3.70 & 5.70 & 3.60 & 5.80 & 0.004 & 0.998 & 0.009 & 0.833 \\
\hline EDCP P2 $(\% / h)$ & $49.04 \mathrm{c}$ & $76.64 a$ & $62.52 b$ & $77.23 \mathrm{a}$ & 0.69 & 0.001 & 0.000 & 0.001 \\
\hline EDCP P5 $(\% / h)$ & $37.89 \mathrm{c}$ & $60.46 a$ & $47.27 b$ & $60.08 \mathrm{a}$ & 1.03 & 0.012 & 0.000 & 0.009 \\
\hline
\end{tabular}

Averages within the same row, followed by different letters differ from each other at the 5\% probability level for the interaction; $\mathrm{SD}=$ standard deviation; $\mathrm{DESM}=$ Desmodium; LEUC = Leucaena; CONS = conservation method; FOR = Forage; INT = Interaction; $a=$ rapidly soluble fraction; $\mathrm{b}=$ potentially degradable fraction; $\mathrm{c}=$ fractional rate of degradation in which fraction b; EDCP P2 and EDCP P5 = Effective degradability of crude protein at passage rate of 2 and $5 \% / \mathrm{h}$

The estimated EDCP for the 2 and 5\%/hour passage rates were higher for leucaena $(\mathrm{P}<0.05)$ compared to desmodium. These differences in degradability may be related to variations in specific characteristics of the protein present in each forage, as well as the accessibility of this protein by the digestive enzymes and the presence of tannins and other polyphenols, which may protect the protein fraction from rumen degradation (Veloso et al., 2006). Thus, the high tannin content in desmodium, which according to Abaunza et al. (1991) is around 17\%, may have contributed to the lower CP degradability for this legume. There was an interaction between the conservation method and forage species, where leucaena conserved as hay and silage presented EDCP at 2 and 5\%/hour similar to each other $(\mathrm{P}>0.05)$, but higher than the other treatments. Desmodium conserved as hay and silage differed from each other $(\mathrm{P}>0.05)$ with higher value obtained for the hay. Considering that the forage harvest for silage and hay production occurred at the same vegetative stage, the lower EDCP presented by desmodium silage may be an indicative of Maillard reaction occurrence. According to Pereira and Reis (2001) silages with high DM content are more likely to raise the temperature of the ensiled mass, and when this temperature exceeds $55{ }^{\circ} \mathrm{C}$ reactions can occur between soluble carbohydrates and the amino group of amino acids, resulting in a reduction in $\mathrm{CP}$ availability to rumen microorganisms. 


\section{Conclusion}

Leucaena has a higher nutritional value than desmodium, because it has higher digestibilities of dry matter and cell wall and a higher degradability of dry matter and crude protein. The conservation of legumes as hay had a higher nutritional value than those conserved in the silage form, for most of the parameters. Studies evaluating the use of these legumes preserved as hay and silage to feed cattle are needed to define their effects on milk and meat production.

\section{Acknowledgement}

This study was financed in part by the Coordination for the Improvement of Higher Education Personnel - Brazil (CAPES) - Finance Code 001" and National Institute of Science and Technology of Dairy Production Chain (INCT-LEITE/UEL-PR), Londrina, Paraná, Brazil (CNPq - INCT-Leite, grant number 465725/2014-7) in Brasília, DF, Brazil and Araucaria Foundation, Curitiba, Paraná.

\section{References}

Abaunza, M. A., Lascano, C. E., Giraldo, H., \& Toledo, J. M. (1991). Valor nutritivo y aceptabilidad de gramíneas y leguminosas forrajeras tropicales em suelos ácidos. Pasturas Tropicales, 13(2), 2-9.

Aganga, A. A., \& Tshwenyane, S. O. (2003). Lucerne, Lablab and Leucaena leucocephala Forages: Production and Utilization for Livestock Production. Pakistan Journal of Nutrition, 2(2), 46-53. https://doi.org/10.3923/pjn.2003.46.53

Almeida, A. P. M. G., Kommers, G. D., Nogueira, A. P. A., Júnior, L. G. B., Marques, B. M. F. P., \& Lemos, R. A. A. (2006). Avaliação do efeito tóxico de Leucaena leucocephala (Leg. Mimosoideae) em ovinos. Pesquisa Veterinária Brasileira, 26(3), 190-194. https://doi.org/10.1590/S0100-736X2006000300011

AOAC - Association of Official Analytical Chemists. (1980). Official methods of analysis. (13 ed.) Washington: AOAC.

Barreto, M. L. J., Lima Júnior, D. M., Oliveira, J. P. F., Rangel, A. H. N., \& Aguiar, E. M. (2010). Utilização da leucena (Leucaena leucocephala) na alimentação ruminantes. Revista Verde de Agroecologia e Desenvolvimento Sustentável, 5(1), 07-16.

https://doi.org/10.18378/rvads.v5i1.236

Barrios-Maestre, R., Fariñas, J., Silva-Acuña, R., \& Sanabria, D. (2011). Comportamiento de cinco especies de leguminosas como cobertura viva en palma aceitera en el estado Monagas, Venezuela. IDESIA, 29(2), 29-37. https://doi.org/10.4067/S0718-34292011000200004

Bezerra, L. R., Silva, A. M. De A., Lima, F. H. S. De, Souza, J. E. L., Carvalho Jr, S. B., \& Mello, J. R. M. (2010) Cinética ruminal de espécies forrageiras nativas da caatinga. Scientia Agraria Paranaensis, 9(2), 85-94. http://dx.doi.org/10.1818/sap.v9i2.4581

Cherney, J. H., \& Cherney, D. J. R. (2003). Assessing silage quality. In: D.R. Buxton, R. Muck, J. Harrison (Eds.) Silage Science and Technology (141-198). Madison: ASA, CSSA, and SSSA. 
Costa, J. V., Oliveira, M. E., Moura, R. M. A. S., Costa Júnior, M. J. N., \& Rodrigues, M. M. (2015). Comportamento em pastejo e ingestivo de caprinos em sistema silvipastoril. Revista Ciência Agronômica, 46(4), 865-872. https://doi.org/10.5935/1806-6690.20150075

Costa, K. C. G., Maneschy, R. Q., Castro, A. A., Guimarães, T. P., \& Oliveira, I. K. S. (2011). Avaliação da qualidade nutricional da leucena em banco forrageiro de corte no sudeste do Pará. Revista Agroecossistemas, 3(1), 7-12. https://doi.org/10.18542/ragros.v3i1.1059

Costa, N. L., \& Oliveira, J. R. C. (1999). Rendimento de matéria seca e composição química de genótipos de Desmodium em Rondônia. Pesquisa Agropecuária Gaúcha, 5(1), 77-81.

Cruz, E. D. (1993). Produção de sementes e cobertura do solo de Desmodium ovalifolium Wall. Pasturas Tropicales, 15(3), 29-32.

Evangelista, A. R.; Lima, J. A. (2013). Produção de feno. Informe Agropecuário, 34(277), 43-52.

Macedo, R., Tarré, R. M., Ferreira, E., Rezende, C. P., Pereira, J. M., Cadisch, G., Rouws, J. R. C., Alves, B. J. R., Urquiaga, S., \& Boddey, R. M. (2010). Forage intake and botanical composition of feed for cattle fed Brachiaria/legume mixtures. Scientia Agricola, 67(4), 384-392. https://doi.org/10.1590/S0103-90162010000400002

Makkar, H. P. S. (2003). Effects and fate of tannins in ruminant animals, adaptation to tannins and strategies to overcome detrimental effects of feeding tannin-rich feeds. Small Ruminant Research, 90, 209-231. https://doi.org/10.1016/S0921-4488(03)00142-1

Manella, M. Q., Lourenço, A. J., \& Leme, P. R. (2002). Recria de bovinos nelore em pastos de brachiaria brizantha com suplementação protéica ou com acesso a banco de proteína de Leucaena lecocephala. Desempenho Animal. Revista Brasileira de Zootecnia, 31(6), 2274-2282. https://doi.org/10.1590/S1516-35982003000400028

McDonald, P., Henderson, A. R., \& Heron, S. J. E. (1991). Biochemistry of Silage. (2 Ed.) Marlow: Chalcombe.

Morgado, E. S.; Almeida, F. Q.; Silva, V. P.; Gomes, A. V. C.; Galzerano, L.; Ventura, H. T.; \& Rodrigues, L. M. (2009). Digestão dos carboidratos de alimentos volumosos em eqüinos. Revista Brasileira de Zootecnia, 38(1), 75-81.

https://doi.org/10.1590/S1516-35982009000100010

Müller, L., Manfron, P. A., Santos, O. S., Medeiros, S. L. P., Neto, D. D., Morselli, T. B. G. A., ... Bandeira, A. H. (2006). Efeito de soluções nutritivas na produção e qualidade nutricional da forragem hidropônica de trigo (Triticum aestivum L.). Zootecnia Tropical, 24(2), 137-152.

Orskov, E. R., \& Mcdonald, I. (1979). The estimation of protein degradability in the rúmen from incubation measurements weighed according to rate of passage. Journal Agricultural Science, 92, 499-503. https://doi.org/10.1017/S0021859600063048

Pereira, J. R. A., \& Reis, R. A. (2001). Produção de silagem pré-secada com forrageiras temperadas e tropicais. Anais do Simpósio Sobre Produção e Utilização de Forragens Conservadas (64-86). Maringá: Universidade Estadual de Maringá. 
Pires, A. J. V., Reis, R. A., Carvalho, G. G. P., Siqueira, G. R., Bernardes, T. F., Ruggieri, A. C., Almeida, E. O., \& Roth, M. T. P. (2006). Degradabilidade ruminal da matéria seca, da fração fibrosa e da proteína bruta de forrageiras. Pesquisa Agropecuária Brasileira, 41(4), 643-648. https://doi.org/10.1590/S0100-204X2006000400014

Possenti, R. A., Franzolin, R., Schammas, E. A., Demarchi, J. J. A. A., Frighetto, R. T. S., \& Lima, M. A. (2008). Efeitos de dietas contendo Leucaena leucocephala e Saccharomyces cerevisiae sobre a fermentação ruminal e a emissão de gás metano em bovinos. Revista Brasileira de Zootecnia, 37(8), 1509-1516.

https://doi.org/10.1590/S1516-35982008000800025

Schocken-Iturrino, R. P., Reis, R. A., Coan, R. M., Bernardes, T. F., Panizzi, R. C., Poiatti, M. L., \& Pedreira, M. S. (2005). Alterações químicas e microbiológicas nas silagens de capim-tifton 85 após a abertura dos silos. Revista Brasileira de Zootecnia, 34(2), 464-471. https://doi.org/10.1590/S1516-35982005000200013

Silva, D. J., \& Queiroz, A. C. (2002). Análises de alimentos (métodos químicos e biológicos) (3 ed.) Viçosa: Editora UFV.

Teixeira, V. I., Dubeux Jr., J. C. B., Santos, M. V. F., Lira Jr., M. A., Lira, M. A., \& Silva, H. M. S. (2010). Aspectos agronômicos e bromatológicos de leguminosas forrageiras no nordeste brasileiro. Archivos de Zootecnia, 59(226), 245-254.

https://doi.org/10.4321/S0004-05922010000200010

Tilley, J. M. A., \& Terry, R. A. (1963). A two stage technique for the in vitro digestion of forage crops. Journal British of Grassland Society, 18(2), 104-111.

https://doi.org/10.1111/j.1365-2494.1963.tb00335.x

Veloso, C. M., Rodriguez, N. M., Carvalho, G. G. P., Pires, A. J.V., Mourão, G. B., Gonçalves, L. C., \& Sampaio, I. B. M. (2006). Degradabilidade ruminal da matéria seca e da proteína bruta de folhas e folíolos de forrageiras tropicais. Revista Brasileira de Zootecnia, 35(2), 613-617. https://doi.org/10.1590/S1516-35982006000200039

Veloso, C. M., Rodriguez, N. M., Sampaio, I. B. M., Gonçalves, L. C., \& Mourão, G. B. (2000). pH e amônia ruminais, relação folhas:hastes e degradabilidade ruminal da fibra de forrageiras tropicais. Revista Brasileira de Zootecnia, 29(3) 871-879.

https://doi.org/10.1590/S1516-35982000000300033

Weiss, P. W. (1993). Predicting energy values of feeds. Journal of Dairy Science, 76(6), 1802-1811. https://doi.org/10.3168/jds.S0022-0302(93)77512-8

\section{Copyright Disclaimer}

Copyright for this article is retained by the author(s), with first publication rights granted to the journal.

This is an open-access article distributed under the terms and conditions of the Creative Commons Attribution license (http://creativecommons.org/licenses/by/4.0/). 